\title{
EDITORIAL NOTE Proceedings of the Third Gondwanan Dinosaur Symposium
}

\author{
ALEXANDER W.A. KELLNER ${ }^{1}$ and YUKIMITSU TOMIDA ${ }^{2}$
}

In the last two decades, the information about dinosaurs from Gondwana has increased tremendously. In order to discuss the important discoveries of these and other reptiles that once lived in this ancient supercontinent, several researchers organized the symposium "Gondwana Dinosaurs: Phylogeny and Paleobiogeography". This meeting was the highlight of the VI Argentine Congress of Paleontology and Biostratigraphy held in Trelew, Chubut, Argentina, between April $3^{\text {rd }}$ and $8^{\text {th }}, 1994$. The success of this symposium, the first one of this kind, led to the "Second Gondwanan Dinosaur Symposium", organized at the National Science Museum (now National Museum of Nature and Science) in Tokyo between July $12^{\text {th }}$ and $13^{\text {th }}, 1998$.

A little over a decade later, the National Museum of Nature and Science and the Yomiuri Shimbun decided to host, again in Tokyo, the "Third Gondwanan Dinosaur Symposium". This event was part of the wonderful exhibition on dinosaurs and associated fauna that took place between March $14^{\text {th }}$ and June $21^{\text {st }}, 2009$ at the National Museum of Nature and Science. Sponsored by the Brazilian Academy of Sciences and the Yomiuri Shimbun, the present volume presents the main contributions discussed during this meeting. Since not everyone who wished could attend the symposium, several authors were invited to contribute to this volume, which includes dinosaurs and associated faunas.

As a result, there are 20 original papers, more than in the volumes of the previous symposia, concerning several aspects regarding Gondwanan dinosaurs. The highlights include the contribution of Jacobs et al. (2011) that focus on some historical biogeographic fundaments applied to dinosaurs using broad paleoclimatic principles to trace localities through latitudinal climate zones. Among other topics, these authors discuss concepts like Noah's Arks and Beached Viking Funeral Ships that were previously outlined by McKenna (1973) and put forward by others to explain the distribution of dinosaurs in Gondwana. On the same line, Bittencourt and Langer (2011) provide an excellent summary of the current knowledge about Brazilian dinosaurs and what we can learn from them regarding biogeography.

New dinosaurs are also being reported. These include a small deinonychosaur theropod dinosaur from the Portezuelo Formation (Turonian-Coniacian) of Argentina, which increases the diversity of these carnivorous dinosaurs in South America (Porfiri et al. 2011). Another new species whose reconstruction illustrates the cover of this volume is a spinosaurid from Brazil that has strong affinities with African forms. With an estimated length of 12 to 14 meters, the new taxon represents the largest Mesozoic carnivore from the country described so far (Kellner et al. 2011). Still regarding theropods, Agnolin and Novas (2011) discuss the phylogenetic position of the Unenlagiidae, a bizarre dinosaur clade that has fostered some controversy.

\footnotetext{
${ }^{1}$ Departamento de Paleontologia e Geologia, Museu Nacional/UFRJ. Quinta da Boa Vista s/n, São Cristóvão, Rio de Janeiro, Brazil.

${ }^{2}$ National Museum of Nature and Science, 3-23-1 Hyakunin-cho, Shinjuku-ku, Tokyo 169-0073, Japan.
} 
EDITORIAL NOTE

Studies regarding sauropods are also presented in this volume. Among these is the description of the first dinosaur from Angola, a country with high potential for fossil vertebrates. The species represents a non-titanosaur from sub-Saharan Africa that during the Cretaceous was dominated by titanosaurian taxa (Mateus et al. 2011). Gonzáles Riga (2011) presents an excellent evaluation of trackways attributed to Titanopodus mendozensis, producing new information about the locomotion of titanosaurian sauropods, and Saegusa and Tomida (2011) provide an extensive review of titanosauriform teeth found in Cretaceous deposits of Japan.

Last but not least, this volume also presents some new information about non-dinosaur vertebrates that shared spaces and environments with these reptiles. Among the most interesting contributions is the description of a new squamate lizard from the Adamantina Formation (Upper Cretaceous) of the Bauru Basin (Nava and Martinelli 2011). Despite being fragmentary, the specimen presents morphological features, comes from a distinct stratigraphic horizon and geographical area from previously described taxa that are paramount in the recognition of species in the fossil record (see Kellner 2010), and has allowed the authors to increase the Mesozoic squamate lizard diversity of South America otherwise poorly known.

We would like to thank all the authors who have attended the Symposium in Tokyo and those who have contributed to this volume. Our special thanks goes to Yomiuri Shimbun for both financing the incredible second version of the Gondwanan Dinosaur exhibit and part of the costs of the present publication.

\section{REFERENCES}

AgNolin FL AND Novas FE. 2011. Unenlagiid theropods: are they members of the Dromaeosauridae (Theropoda, Maniraptora)? An Acad Bras Cienc 83: 117-162.

BitTencourt JS AND LANGer MC. 2011. Mesozoic dinosaurs from Brazil and their biogeographic implications. An Acad Bras Cienc 83: 23-60.

GonZÁLEZ Riga BJ. 2011. Speeds and stance of titanosaur sauropods: analysis of Titanopodus tracks from the Late Cretaceous of Mendoza, Argentina. An Acad Bras Cienc 83: 279-290.

Jacobs LL, Strganac C And Scotese C. 2011. Plate Motions, Gondwana Dinosaurs, Noah's Arks, Beached Viking Funeral Ships, Ghost Ships, and Landspans. An Acad Bras Cienc 83: 3-22.

Kellner AWA. 2010. Comments on the Pteranodontidae (Pterosauria, Pterodactyloidea) with the description of two new species. An Acad Bras Cienc 82: 1063-1084.

Kellner AWa, Azevedo SAK, Machado EB, Carvalho LB and Henriques DDR. 2011. A new dinosaur (Theropoda, Spinosauridae) from the Cretaceous (Cenomanian) Alcântara Formation, Cajual Island, Brazil. An Acad Bras Cienc 83: 99-108.

Mateus O, Jacobs ll, Schulp as, Polcyn mu, tavares tS, neto AB, Morais Ml and antunes Mt. 2011. Angolatitan adamastor, a new sauropod dinosaur and the first record from Angola. An Acad Bras Cienc 83: 221-233.

McKenna MC. 1973. Sweepstakes, filters, corridors, Noah's Arks, and Beached Viking Funeral Ships in palaeogeography. In: TARLING DH AND RUNCORN SK (Eds), Implications of Continental Drift to the Earth Sciences. Academic Press, New York, p. 295-308.

NAVA WR and Martinelli AG. 2011. A new squamate lizard from the Upper Cretaceous Adamantina Formation (Bauru Group), São Paulo State, Brazil. An Acad Bras Cienc 83: 291-299.

PoRfiri JD, CALVo JO AND SAntos D. 2011. A new small deinonychosaur (Dinosauria: Theropoda) from the Late Cretaceous of Patagonia, Argentina. An Acad Bras Cienc 83: 109-116.

SAegusa H AND Tomida Y. 2011. Titanosauriform teeth from the Cretaceous of Japan. An Acad Bras Cienc 83: 247-265. 